\title{
The Pennsylvania State University -Materials Research Institute-
}

中 嶋 浩 善*

\section{1.はじめに}

ペンシルバニア州立大学（図 1) は 1855 年に農業大学 して設立され，現在ではペンシルバニア州内に 24 ケ所の キャンパスを有する全米屈指の総合大学である.メイン キャンパスである University Park キャンパスは米国北東 部ペンシルバニア州の真ん中に位置し, New York, Washington DC, Philadelphia, Pittsburg 等の主要都市まで高 速道路を走って 4 5 時間の至近距離にある.アパラチア 山脈に囲まれた自然豊かな広大なキャンパスでは約 35,000 人の学部生・約 6,600 人の大学院生・約 2,400 人 の教職員が在籍し, 理学・工学・材料科学・情報技術・農 学・教育学・教養学・経済・芸術など幅広い分野の研究が 行われている.

\section{2. 材料研究を担う組織}

Materials Research Institute (MRI：図 2) は, 4 学部 15 学科に在籍する 200 名以上の教授陣との連携によって, 材料研究全般の運営・統括を行っている. 材料研究の組織 は1）研究センター, 2) 研究施設, 3) 学部・学科の 3 つ に大別される. また，企業との共同研究の促進，知的財産 の技術移転を行う組織もある.

\section{1 ) 研究センター}

ある特定の研究課題に焦点を当てた研究者らが学際的研 究グループを形成する. 研究センターの数は 20 以上にも のほりり, 金属・七ラミック・高分子と非常に幅広い研究分 野を網羅している.

a. Center for Nanoscale Science

The National Science Foundation（NSF）により設立さ れた材料研究に関するセンター (The Materials Research Science and Engineering Center (MRSEC)). 約 85 名の 教官・博士研究員・大学院生らにより下記の 3 つのシード プログラムが進められている.

- Chemical Nanolithography

- Molecular Motor

- Collective Dynamics of Photons, Fluids, and Electrons

\footnotetext{
* Nakajima, Hiroyoshi

住友化学工業(侏石油化学品研究所

袖ヶ浦市北袖 2-1（开299-0295）

2003.8.1 受理
}

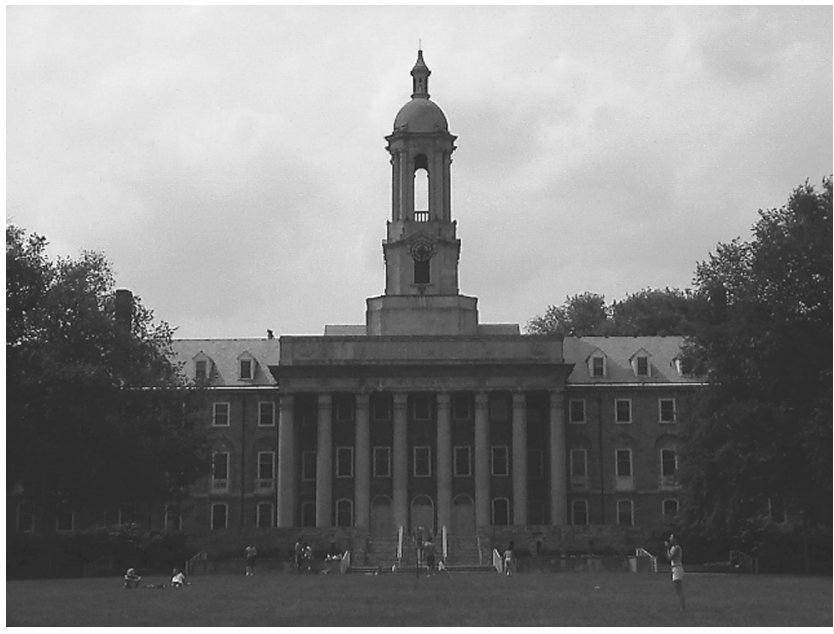

図 1 Pennsylvania State University (Old Main, University Park, PA)

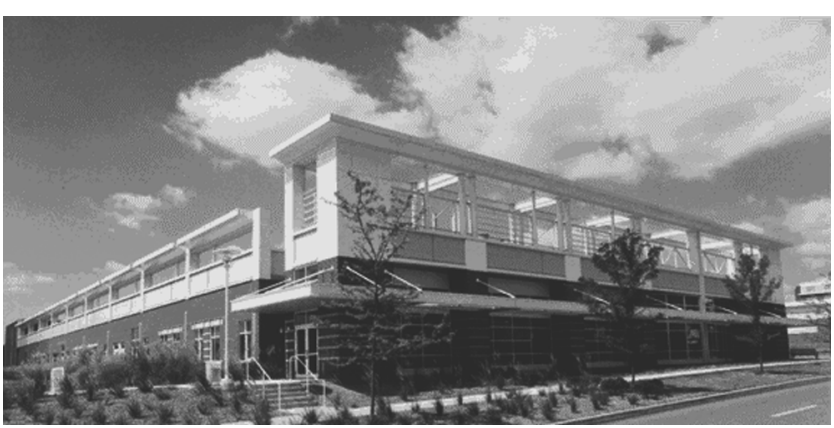

図 2 Materials Research Institute (Penn State Nanofabrication Facility)

within Ordered Nanostructured Matter

b. The Center for the Study of Polymer-Solvent Systems

拡散挙動・相平衡に重点を扔いた高分子一溶媒系に関す る研究が行われている，当センターと共同研究を進めてい る企業は $3 \mathrm{M} \cdot$ Air Products $\cdot$ Atofina $\cdot$ Dow $\cdot \mathrm{GE} \cdot$ 三菱 化学などである。

\section{2 ) 研究施設}

大型の分析・加工装置やコンピュー夕を配備した $6 つ の$ 研究施設がある.

a. Penn State Nanofabrication Facility (Nano Fab) NSF により設立された National Nanofabrication User 


\begin{tabular}{|c|c|}
\hline 〈教官〉 & $\langle$ 研究内容〉 \\
\hline David Allara & $\begin{array}{l}\text { - Sensitive molecular-structure probes } \\
\text { - Informative model chemical structures }\end{array}$ \\
\hline Harry R. Allcock & $\begin{array}{l}\text { - Design and synthesis of new polymers that contain organic components, together with heteroele- } \\
\text { ments such as P, Si, B, or transition metals }\end{array}$ \\
\hline T.C. Mike Chung & $\begin{array}{l}\text { - Functionalization of polyolefins } \\
\text { - Borane-based living radical initiators and polymerization } \\
\text { - Electro-active and ferroelectric polymers }\end{array}$ \\
\hline Ralph H. Colby & $\begin{array}{l}\text { - Polymer dynamics } \\
\text { - Rheology of polymer melts, blends, solutions, gels, and other complex fluids }\end{array}$ \\
\hline Michael M. Coleman & $\begin{array}{l}\text { - Application of vibrational spectroscopy to the study of multicomponent polymer systems } \\
\text { - Search for additives that retard the formation of carbonaceous solids in jet fuels }\end{array}$ \\
\hline Ian H. Harrison & - Understanding and developing polyethylene-based materials \\
\hline Sanat K. Kumar & $\begin{array}{l}\text { - Thermodynamics of complex condensed phase systems } \\
\text { - Polymers at surfaces and interfaces } \\
\text { - Glass transition phenomena } \\
\text { - Dynamics of macromolecular liquids }\end{array}$ \\
\hline E. Manias & $\begin{array}{l}\text { - Structure and dynamics of nano-confined polymers } \\
\text { - Atomic force microscopy (AFM) studies of polymers } \\
\text { - Polymer/inorganic nanocomposite materials } \\
\text { - Smart/responsive polymers }\end{array}$ \\
\hline Janna K. Maranas & - Molecular simulation to understand the microscopic origins of various phenomena \\
\hline Paul C. Painter & - Effects of strong intermolecular interactions on the properties of polymers \\
\hline Carlo G. Pantano & - Effect of composition and treatment of glass surfaces on adhesion of polymer coatings \\
\hline James P. Runt & $\begin{array}{l}\text { - Crystalline polymers and polymer blends } \\
\text { • Biomedical polyurethanes }\end{array}$ \\
\hline Ayusman Sen & - New late-transition metal-based polymerization catalyst \\
\hline Erwin Vogler & - Biomaterials/biomaterials surface science \\
\hline Qing Wang & $\begin{array}{l}\text { - Semiconducting organic/inorganic hybrid nanostructures for optoelectronics } \\
\text { - Biomimetic assembly and patterning of conjugated polymers } \\
\text { - Bioactive polymer brushes } \\
\text { - Applications in nanomachines and biosensors }\end{array}$ \\
\hline
\end{tabular}

Network（NNUN）の一部であり, コーネル大学・ハワー ド大学・スタンフォード大学・カリフォルニア大学サンタ バーバラ校も NNUN に属し, Nano Fabと同様の施設を 有する. Nano Fabではサブミクロンサイズの構造の構築 を目的としており, 電子工学・光学・量子物理から生物 学・医学に至るまで幅広い分野を網羅している。2 2300 万 ドル相当の装置群（クリーンルーム・電子顕微鏡 (STM/ AFM/FE-SEM/Difference Frequency STM) • Electron Beam Lithography - Low Pressure Chemical Vapor Deposition System など) を有しており，専門スタッフが 常勤している．年間利用者数は約 400 名程度で，世界中の 大学・企業の利用がある.

また, NSF・NNUN と共同で学部学生向けナノテクノ ロジー教育/研究プログラムが進められており, 教育機関 としての一面も持つ.

Nano Fabで進められている高分子関連のプロジェクト は以下の通りである。

- Polymer Filaments

- New polymer optical waveguides with integrated gratings for tunable passive optoelectronic devices for telecommunications b. Materials Characterization Laboratory (MCL)

電子顕微鏡 (SEM, TEM) ・ 表面/薄膜分析 (XPS/ESCA, FE-Auger, SIMS, EPMA） - 構造分析（WAXD, SAXS）・ 熱分析（DSC, TGA） - 分光分析（FTIR, Raman, UV-Vis） などのあらゆる分析装置を有している.

\section{3 ) 学部・学科}

上述のように 4 学部 15 学科にて材料研究が行われてい るが, 高分子関連の材料研究は下記の 3 学科で行われて いる. 主な教官陣とその研究内容を表 1 に示す.

- Department of Chemistry

- Department of Chemical Engineering

- Department of Materials Science \& Engineering(図 3) 〈新規高分子材料の創製〉

a. 官能基変性ポリオレフィン

Chung 研究室ではメ夕ロセン触媒による官能基（極性 基) 変性ポリオレフィンの合成が研究されている.オレフィ ンと反応性モノマー（有機ボラン・p-メチルスチレン・ ジビニルベンゼン）との共重合により反応性モノマーの導 入されたポリオレフィン重合後，ポリオレフィン鎖中の反 応性モノマーを水酸基・無水マレイン酸基・アミン基など の官能基に転化させる事で, 官能基変性ポリオレフィンが 
表 2 ポリプロピレン/フッ素変性有機化クレイナノコンポジットの諸物性 ${ }^{11}$

\begin{tabular}{lccc}
\hline Properties & Neat PP & \multicolumn{2}{c}{ PP/f-mmt Nanocomposites } \\
& & 3-wt\%f-mmt & 6-wt\%f-mmt \\
\hline $\begin{array}{l}\text { Mechanical Properties } \\
\text { Young's (tensile) modulus (MPa) }\end{array}$ & 665.8 & 906.9 & 959.3 \\
Yield stress (MPa) & 28.9 & 31.3 & 30.6 \\
Strain at break (\%) & 744.6 & 646.9 & 716.5 \\
Other Properties & & & \\
Heat-deflection temperature $\left({ }^{\circ} \mathrm{C}\right)$ & 109 & 144 & 152 \\
Max. heat-release rate $\left(\mathrm{kWm}^{-2}\right)$ & 1508 & 452 & 390 \\
Light transmittance $($ at $\lambda=600 \mathrm{~nm})$ & 0.58 & 0.57 & 0.49 \\
\hline
\end{tabular}

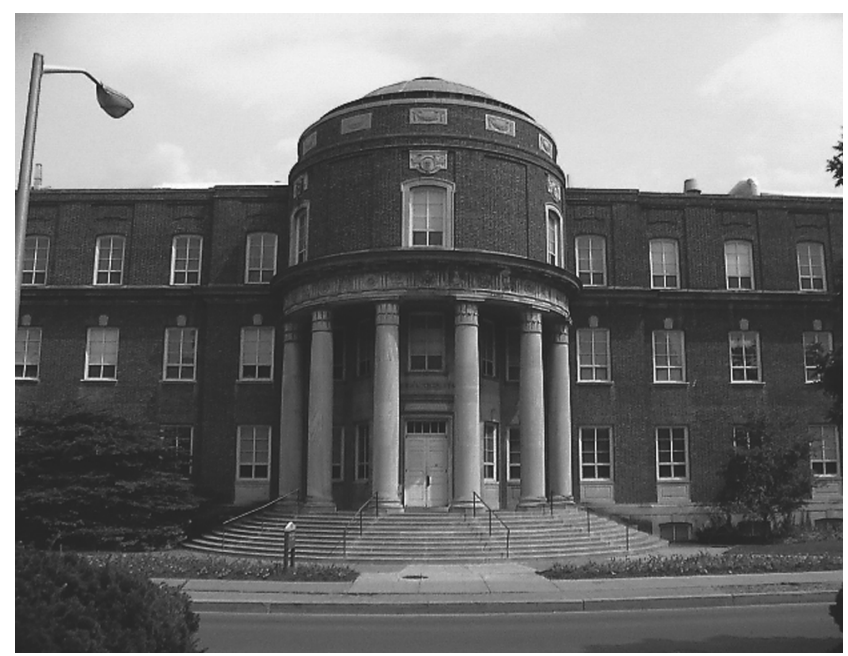

図 3 Department of Materials Science \& Engineering (Steidle Building)

得られる。また触媒・重合条件の選択により反応性モノ マーの導入部位（分子鎖中もしくは分子鎖末端）を制御で きる．本技術により，従来技術（前周期遷移金属を活性種 とする触媒による重合）では難しかった，重合による極性 基変性ポリオレフィンの合成が可能となる．また上記で得 られた官能基変性ポリオレフィンの用途（新規相溶化剂・ 長鎖分岐ポリプロピレンなど）も平行して検討されている。 b. 刺激応答性ポリマー

低温では親水性（水溶性）であるが，ある温度以上にな ると疎水性（水不溶性）となる性質をもつ温度応答性ポリ マーの合成が研究されている. 同ポリマーは親水部/疎水 部からなり，親水部/疎水部の長さ比を変化させる事で LCST (Lower Critical Solution Temperature：下限臨界 溶液温度（水溶性～水不溶性に変化する温度)）を制御で きる $\left(7 \sim 70^{\circ} \mathrm{C}\right)$.また $\mathrm{AFM} に$ にる直接観察により同ポリ マーの構造変化も研究されている. 一方で薬物伝達システ ムなどのバイオテクノロジー関連や基材の表面処理剤（濡 れ性の制御：親水性に疎水性）などへの用途展開も研究さ れている.

c. ポリマークレイナノコンポジット

Manias 研究室ではポリマーマトリックス中にクレイを ナノ分散したポリマークレイナノコンポジットの合成拉よ びその各種物性が研究されている。ポリマーマトリックス
としてはポリエチレンオキサイド・ポリビニルアルコー ル・ポリスチレン・ポリエチレン・ポリプロピレン・ポリ エチレンテレフタレート・ポリウレタン・エポキシ樹脂な ど多種多様であり，クレイの添加による各種物性（力学物 性（弾性率・熱変形温度）・ガスバリア性・難燃性など： 表 2）の向上が期待される.

一方でポリマークレイナノコンポジットをナノ空間（ク レイ層間）に閉じ込められたポリマーのモデル系と見たて， Confinement 下にあるポリマー鎖の挙動についても研究さ れている.

\section{4) 技術移転}

a. Intellectual Property Office (IPO)

IPO では研究にて得られた知見の特許性, 大学所有知的 財産の商品価值・市場性の評価を行い，知的財産の技術移 転・施行の促進を行っている. 年間 100 件近くの特許出願 が行われており, 特許権使用料による歳入は 200 万ドルを 超える（2001 年度）。

b. Industrial Research Office (IRO)

企業との共同研究・委託研究の促進を目的としており, 企業のニーズに応じた研究者の斡旋業務などを行っている.

\section{3. 謝辞}

最後に，本稿を作成するにあたりご協力をいただきまし たペンシルバニア州立大学 Department of Materials Science \& Engineering $の$ E. Manias 教授, T. C. Mike Chung 教授, A. Kimel 教授, Dr. M. Rackaitis に謝意を表します.

\section{参 考 文 献}

1) “A Direct-Blending Approach for Polypropylene/ Clay Nanocomposites Enhances Properties" MRS Bulletin, 26 (11), 862 (2001)

〈ペンシルバニア州立大学〉

Penn State University, University Park, PA 16802 U.S.A.

Home Page : http ://www.psu.edu/ (Penn State)

http : //www.mri.psu.edu/ (MRI)

http : //www.matse.psu.edu/

(Department of Materials Science \& Engineering)

E-mail : hiroyoshi@plmsc.psu.edu 